\title{
What do we know about hybridization among bryophytes in nature?
}

\author{
Rayna Natcheva and Nils Cronberg
}

\begin{abstract}
Despite being recognized as a widespread and evolutionary important phenomenon among vascular plants, interspecific hybridization among bryophytes has been strongly underestimated. In the present review, we summarize knowledge about bryophyte hybrids that are found in nature. Mechanisms of reproductive isolation in bryophytes are compared with those in vascular plants. The morphological and genetic features of sporophytic hybrids and their gametophytic progeny are discussed, as well as some inferences about hybrid fitness. The data available indicate that spontaneous hybridization among bryophytes is not uncommon and has an important, though still not completely understood, evolutionary significance. The existence of many allopolyploid taxa supports this conclusion. Finally we suggest some methods for further investigation of hybridization among bryophytes in nature.
\end{abstract}

Key words: hybridization, bryophytes, isolating mechanisms, evolution, hybrid fitness, hybrid features.

Résumé : Bien qu’on la reconnaisse comme un phénomène généralement répandu et évolutivement important chez les pantes vasculaires, l'hybridation interspécifique a été fortement sous-estimée, chez les bryophytes. Dans cette revue, les auteurs résument la connaissance sur les bryophytes hybrides qu'on retrouve en nature. On compare les mécanismes d'isolement reproductif des bryophytes avec ceux des plantes vasculaires. On discute des caractéristiques morphologiques et génétiques des hybrides sporophytiques et de leur progéniture gamétophytique, ainsi que de certaines déductions sur l'adaptabilité des hybrides. Les données disponibles indiquent que chez les bryophytes, l'hybridation spontanée n'est pas rare et joue un rôle important et significatif dans leur évolution, bien qu'elle soit encore peu comprise. L'existence de plusieurs taxons alloploïdes supporte cette conclusion. Enfin, les auteurs suggèrent quelques méthodes pour poursuivre la recherche sur l'hybridation des bryophytes en nature.

Mots clés : hybridation, bryophytes, mécanismes d'isolement, évolution, adaptabilité des hybrides, caractéristiques des hybrides.

[Traduit par la Rédaction]

\section{Introduction}

Interspecific hybridization has long been recognized as a widespread and important phenomenon in plant evolution (Rieseberg 1995; Burke and Arnold 2001). Stebbins (1950) pointed out that in nearly all cases when a group is considered "critical" or intrinsically difficult to classify, recent interspecific hybridization or past reticulations seem to be involved. Some interspecific hybrids are promptly eliminated by natural selection and appear to be evolutionarily insignificant. Others are persistent and, if at least partly fertile, may lead to the formation of hybrid swarms and hy-

Received 7 May 2004. Published on the NRC Research Press Web site at http://canjbot.nrc.ca on 7 December 2004.

R. Natcheva ${ }^{1}$ and N. Cronberg. Plant Ecology and Systematics, Department of Ecology, Lund University, Sölvegatan 37, 22362 Lund, Sweden.

${ }^{1}$ Corresponding author (e-mail: Rayna.Natcheva@ekol.lu.se). brid zones. Natural hybridization through introgression may facilitate the transfer of genes (and characters, respectively) between different evolutionary units (e.g., species) and thus contributes to the increase of genetic diversity and the establishment of new potentially adaptive genotypes. Hybridization may induce the breakdown or reinforcement of reproductive barriers between closely related groups (Petit et al. 1999). Finally, natural hybridization may give rise to new ecotypes and species. Stebbins (1950) estimated that reticulation events are involved in the origin of more than $50 \%$ of the species of vascular plants. Formation of allopolyploid species by doubling the chromosome set is the most straightforward and the most widely recognized mode of hybrid speciation in plants (Grant 1981; Rieseberg 1997). Homoploid (recombinant) hybrid speciation at the diploid level, that was long mainly a matter of theoretical consideration, has recently been documented to occur in several groups of vascular plants (reviewed in Rieseberg 1997; Rieseberg and Carney 1998). Hybridization is often the reason for discrepancy and low support of phylogenies obtained by combina- 
tion of nuclear and chloroplast DNA sequences or sequences of different nuclear genes (Xu 2000; A.J. Shaw, C.J. Cox, S.B. Boles, and L.E. Anderson, Duke University, unpublished data).

Bryologists, however, have rarely accepted hybridization among bryophyte species as anything more than an ephemeral and evolutionarily insignificant phenomenon (Andrews 1942; Vitt 1971; Smith 1978a, 1979; Anderson 1980), a kind of "evolutionary noise". As compared with the large body of knowledge on hybridization among vascular plants, there are strikingly few reports of hybrids among bryophytes and even fewer attempts to explain the underlying mechanisms and their consequences. Although hybridization has been suggested to cause intermixing of characters or to increase variation in some groups (Nyholm 1958; Crundwell and Nyholm 1964; Proskauer 1967; Ochi 1971), the general consensus has been that the effects of interspecific hybridization among bryophytes are confined to the sporophytic phase (Nicholson 1931; Anderson 1980). Consequently, bryologists have usually been reluctant to give hybrids formal taxonomic recognition and few hybrids have received a scientific name and diagnosis if they were initially recognized as such (exceptions being, e.g., Ruthe 1891; Andrews and Hermann 1959; Delgadillo 1989; Schuster 1991; Ros et al. 1994). The assumed rarity of interspecific hybridization events has been invoked as one of the arguments for considering bryophytes a group with low evolutionary potential (Anderson 1963; Crum 1972).

Bryophytes are the oldest extant land plants comprising three major groups, mosses, liverworts, and hornworts, which at present are believed to be only distantly related (Nickrent et al. 2000; Shaw and Goffinet 2000a; Kugita et al. 2003) but united by sharing, among other characters, unique life cycle features. The life cycle of bryophytes is divided into a dominant haploid gametophytic phase and a usually short-lived sessile diploid sporophytic phase. The sporophyte is formed after the fusion of an egg and a sperm, and is the only stage of the life cycle that contains two complete genomes (i.e., is functionally diploid). This means that the term hybrid as applied to bryophytes should strictly speaking be used only for the sporophytic hybrids (Anderson 1980), corresponding to F1 hybrids in vascular plants (Longton and Schuster 1983). Haploid progeny (initially in form of spores) derived from a hybrid sporophyte is a result from meiosis and will display segregation of parental traits. Therefore, they are not strictly comparable to the hybrids observed among higher plants and have accordingly been referred to as "recombinants" by Shaw (1994, 1998). Since the application of the term "hybrid" to recombinant gametophytic progeny will not confuse our further discussion we prefer to keep using it, bearing in mind the above remarks. In theory, hybrids can be detected by means of morphological and genetic methods (at chromosomal or molecular level) in both phases of the bryophyte life cycle.

The first discussions of hybridization among bryophytes were initiated by taxonomists of the 19th century (Bayerhoffer 1849; Ruthe 1873; Geheeb 1876; Sanio 1880, 1887; Venturi 1881; Philibert 1883, 1891; Limpricht 1887; Cardot 1890; Britton 1895). Initially only morphological characters were used to identify hybrids, and mainly sporophytic hybrids were reported. In the middle of the 20th century, cyto- logical methods were used to identify hybrid sporophytes and assess their fertility (Wettstein 1924b, 1928; Khanna 1960; Anderson and Lemmon 1972; Anderson and Snider 1982). More recently, molecular techniques have been introduced to account for hybridization and introgression. Co-dominant molecular markers, such as allozymes and microsatellites, have proved to be useful tools for detecting hybrid origins and especially to uncover cases of allopolyploidy. Contrary to earlier expectations, allopolyploidy has proved to be a common phenomenon among bryophytes (Såstad, in press). DNA sequence data have revealed past hybridization events between remotely related congeneric species (Shaw and Goffinet 2000b).

Attempts to produce controlled crosses between different bryophyte species were initiated by early 20th century geneticists. Wettstein $(1923,1924 a, 1924 b, 1928,1940)$ was the first to demonstrate that species of mosses can be artificially crossed. He worked with species from the Funariaceae and was able to study the cytology of numerous interspecific and intergeneric crosses and reciprocals (listed in Wettstein 1932). Most of these were observed also in nature. Successful crosses between species from the Funariaceae were later obtained by Brosig (1953) and Bauer and Brosig (1959). Artificial crosses were also attempted between liverwort species. In his pioneering works involving Sphaerocarpos, Allen (1930, 1937) investigated character segregation and compatibility between different sib-families, mutant forms, and geographic races of Sphaerocarpos texanus Austin, as well as the crossability of Sphaerocarpos texanus and Sphaerocarpos donnellii Austin. In the order Marchantiales, Burgeff (1943) found a wide range of interfertility between 13 species of Marchantia. Proctor (1972) used crossing experiments to test the occurrence of reproductively isolated geographic races in Riella americana $\mathrm{M}$. Howe and Underw. Artificial crosses between different mutants, geographic races, and species of hornworts were performed by Proskauer (1969). These works show the potential use of controlled crossing experiments for studying various aspects of bryophyte biology.

Our aims in this review are to (1) summarize the scattered pieces of knowledge about hybridization among bryophytes in nature; (2) assess the frequencies and tendencies of hybridization in various bryophyte groups; (3) outline what is known about isolating mechanisms among bryophytes as barriers preventing hybridization; (4) summarize what is known about bryophyte hybrids with respect to morphological expression, genetics, fertility, vegetative fitness; and (5) put forward questions and suggestions for further work.

\section{Materials and methods}

To retrieve articles that report natural interspecific hybrids or describe hybridization processes among bryophytes, we searched the database BIOSIS (The Dialog Corporation 2002), Prof. J.P. Frahm's literature database (available at http://www.bryologie.uni-bonn.de/deutsch/frame.htm), and the bryophyte literature database at the Missouri Botanical Garden (http://mobot.mobot.org/W3T/Search/mbib.html). In addition, the main bryological journals (Transactions of the British Bryological Society, Journal of Bryology, The Bryologist, Revue Bryologique et Lichénologique, Cryptogamie 
Bryologie, Journal of the Hattori Botanical Laboratory, Nova Hedwigia, Lindbergia, Herzogia) were screened from the beginning of their issuing. We also tried to trace additional references that were cited by various authors but not found in the above-mentioned searches.

Tables 1 and 2 provide lists of the known sporophytic and putative gametophytic hybrids and summarize their features. Many reports, especially those before 1960, contain only brief morphological descriptions of the hybrids and their putative parents. Relatively few papers provide more details and comments on the hybridization process. These are more often referred to in our discussion.

\section{Results and discussion}

\section{Frequency of hybrids in various taxonomic groups and different life-history categories}

There is evidence that some groups of flowering plants hybridize more readily than others (Ellstrand et al. 1996; Rieseberg and Carney 1998). Observations of hybridization among bryophytes are also unevenly distributed among taxonomic groups (Tables 1 and 2), being more frequent in the moss families Funariaceae, Ditrichaceae, Pottiaceae (mainly between the sections of Weissia), Bryaceae (mainly in Bryum), and Sphagnaceae. Members of some bryophyte groups are likely to be less effectively reproductively isolated than others. The frequency of hybridization also depends on the degree of divergence. Mosses, liverworts, and hornworts have ancient evolutionary histories, and there are speculations that the mutation rate is low in some groups (Stenøien and Såstad 1999). Hybridization between more remote evolutionary lineages, for example, different sections within a genus (Weissia, Sphagnum) or even different genera (in Funariaceae, Ditrichaceae, Bryaceae), may imply that such taxa have undergone a particularly slow pace of molecular and chromosomal evolution (Stenøien and Flatberg 2000). Alternatively, it is possible that the generic concept differs among groups, and therefore the observed intergeneric hybridization in some cases is a taxonomic artefact.

However, the data presented in Tables 1 and 2 could be biased for several other reasons: (1) Pottiaceae, Ditrichaceae, and Funariaceae incorporate species with very dissimilar sporophytes, and therefore hybrids in the sporophytic stage are easier to notice. Indeed, most of the hybrids in these families are sporophytic. (2) These groups include many bisexual species that abundantly produce gametangia and sporophytes in comparison to the majority of the unisexual species. (3) Some groups have received more attention, for example, Bryum, Sphagnum, and therefore their variation (morphological and (or) molecular) is better studied. (4) Since the bryoflora of the temperate regions is best known, it is not surprising that hybrids are reported predominantly from the Northern Hemisphere. It could be expected that more examples of hybridization will emerge when knowledge about tropical groups accumulates.

It is noteworthy that hitherto hybridization at the haploid level in nature has been documented only between moss species. There is no case of hybrids unequivocally shown to exist between taxa of liverworts (not considering the allopolyploid taxa). Interspecific crossing has been proposed to occur in the unisexual liverwort, Cephaloziella dentata
(Raddi) Mig., based on perianths with unusual morphology (Douin 1927). Douin (1927) suggested that they were due to cross-fertilization by some other species because of their deviating morphology and the fact that only females are known to occur in Europe. However, perianths are developed by gametophytic tissue and are not a result of fertilization itself (Nicholson 1931).

Another putative case of hybridization in hepatics is the haploid species, Marchantia polymorpha L. Burgeff (1943) observed that Marchantia aquatica (Nees) Burgeff and Marchantia alpestris (Nees) Burgeff could be crossed experimentally with difficulty and yielded variable progeny similar to Marchantia polymorpha. In contrast, crosses between either of the putative parents, Marchantia aquatica and Marchantia alpestris, with Marchantia polymorpha were easily obtained. Therefore, he concluded that Marchantia polymorpha is a stabilized hybrid. This hypothesis was favoured by Schuster $(1983,1992)$, who noted the affinity of Marchantia polymorpha to man-made habitats and suggested that its origin dates back only to the prehistoric man. However, recent molecular studies indicate that Marchantia polymorpha is a distinct species without any trace of hybridization in its origin (Boisselier-Dubayle and Bischler 1989; Boisselier-Dubayle et al. 1995).

A similar example is the status of Pellia $\times$ appalachiana R.M. Schust. It was speculated that this taxon is a hybrid between Pellia epiphylla (L.) Corda and Pellia neesiana Gottsche (Schuster 1991, 1992) because it combines characters of both species. However, there are serious arguments against this hypothesis. Self and Crandall-Stotler (2001) found that Pellia $\times$ appalachiana was fully fertile in common garden experiments, it displayed species-specific isozyme variation, and nucleotide sequences for the ITS region of the nuclear genomes of Pellia $\times$ appalachiana, Pellia epiphylla, and Pellia neesiana did not support a putative hybrid origin. Although the cells of $P . \times$ appalachiana are clearly larger than both Pellia epiphylla and Pellia neesiana (Schuster 1992), it is haploid with $n=9$ (B. CrandallStotler, Southern Illinois University, personal communication).

Reticulations probably occur among hornworts. Proskauer (1967) suggested that the observed variability and incongruence between thallus and spore morphology in a number of mixed populations of Phaeoceros himalayense (Kash.) Prosk. and Phaeoceros laevis (L.) Prosk. represented hybrid swarms. The existence of accessory chromosomes and unisexuality of Phaeoceros carolinianus (Michx.) Prosk. were hypothesized to have originated by transfer of genetic material to Phaeoceros laevis from some other species multiple times and in different areas (Proskauer 1957). However, he was unsuccessful in producing any of the putative interspecific crosses experimentally. No molecular investigations have been made to test these hypotheses.

Another notable trend is the prevalence of hybrids among terrestrial bryophytes. There are only a few cases of putative interspecific hybrids among epiphytes, all being from the Orthotrichaceae (Ruthe 1873; Philibert 1883; Smith 1978b; Hedderson 1986). Hybrids are also rarely found among species that grow submerged or in periodically flooded habitats (examples in Sonesson 1966; Hylander 1999). 


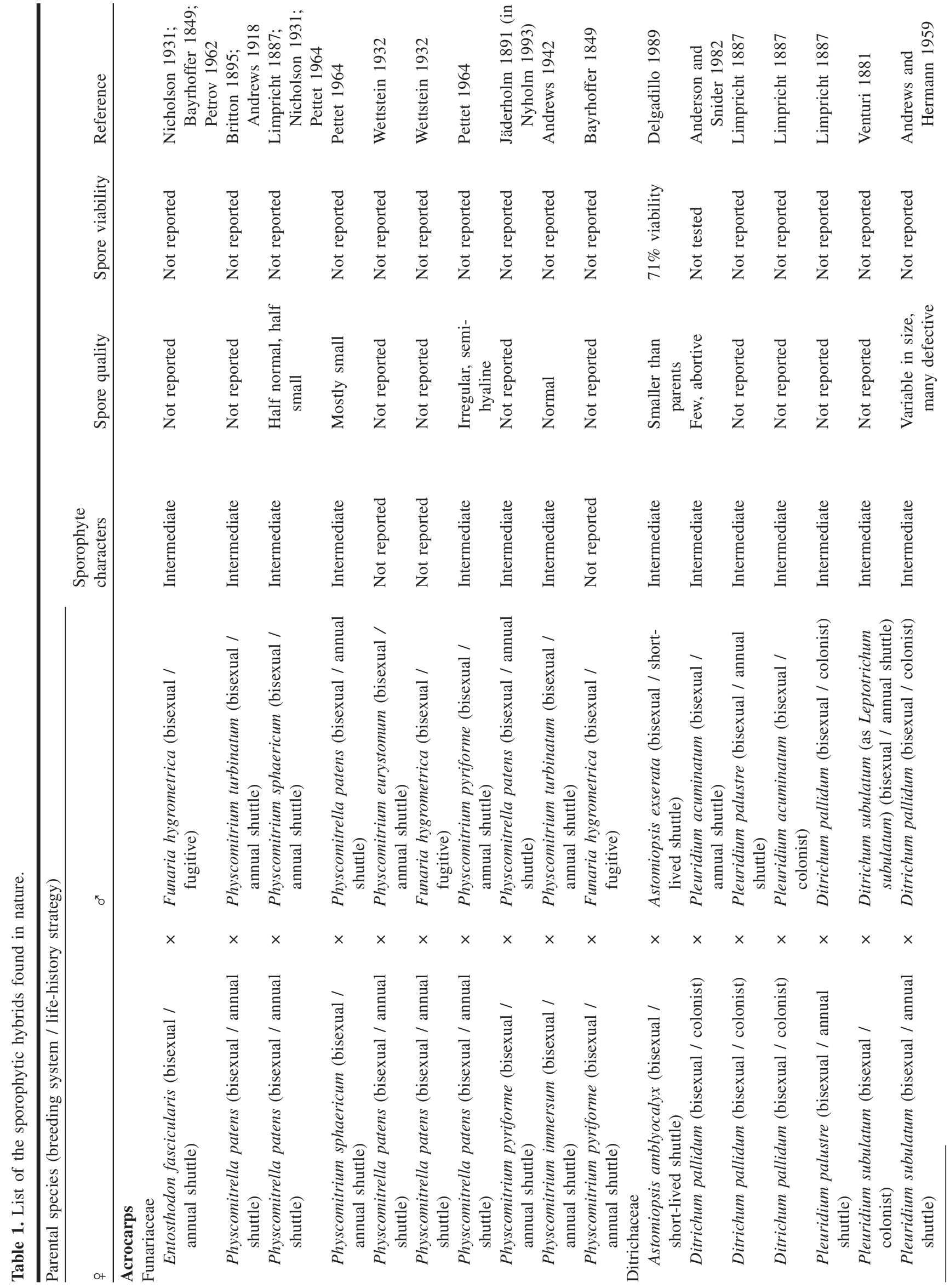




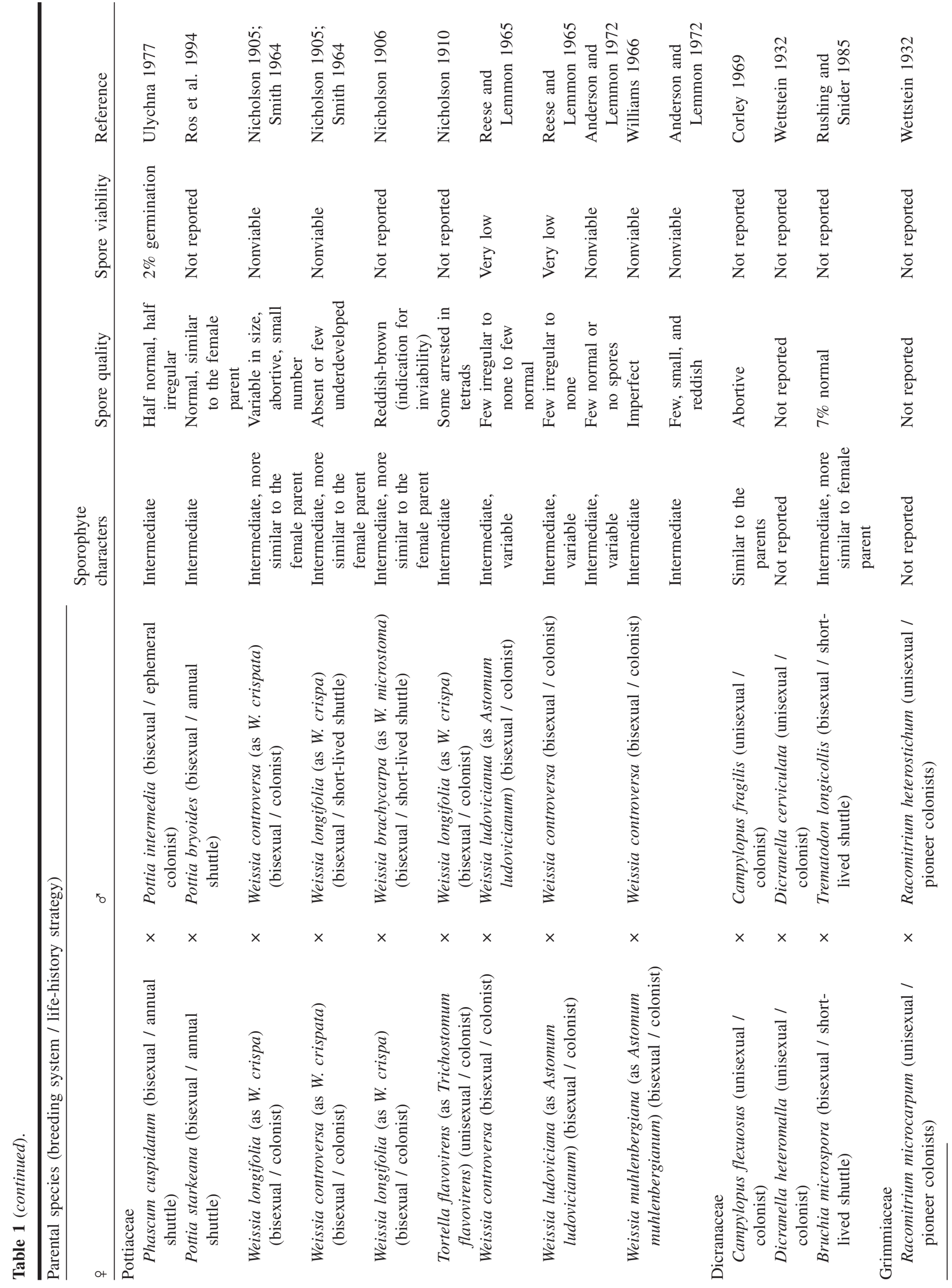




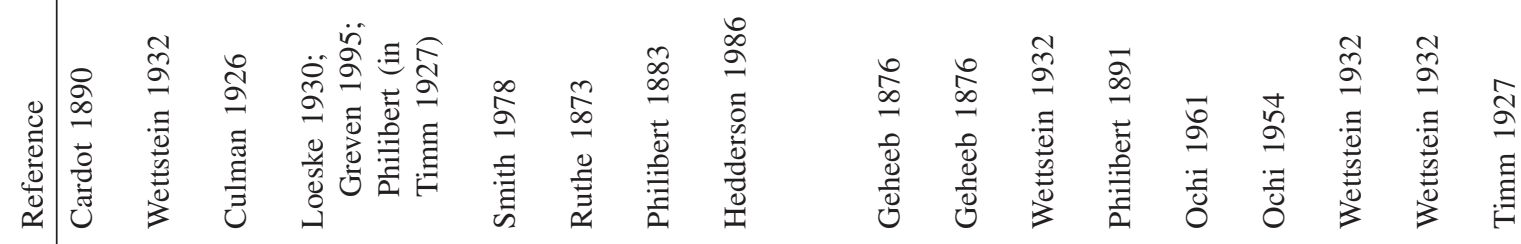

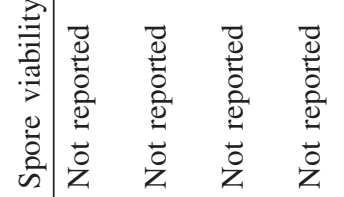

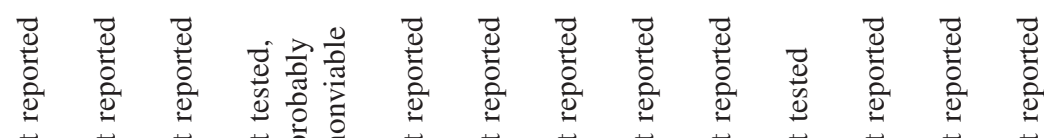

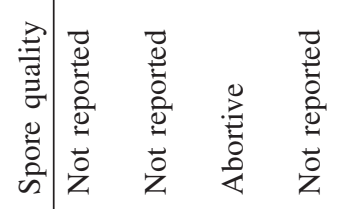








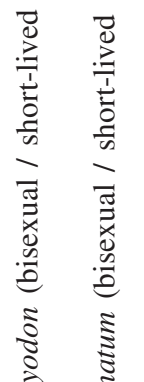
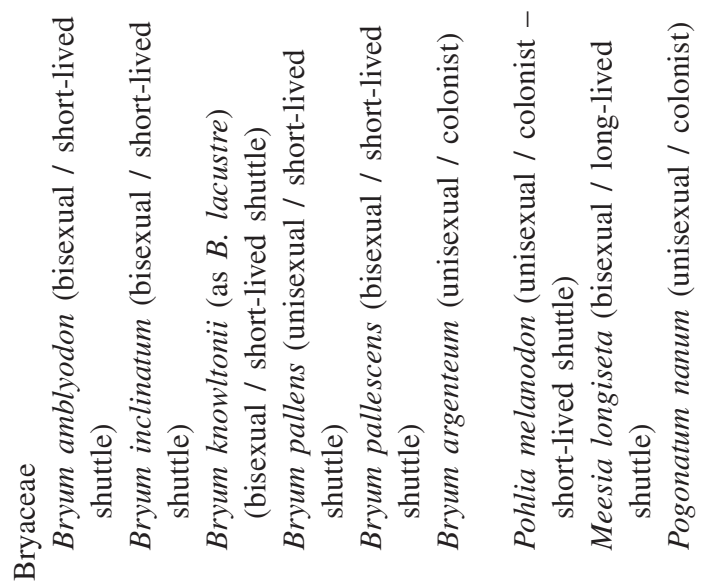
There is an apparent correlation between life-history strategy (after During 1992) and the frequency of observed hybrids (Tables 1 and 2). Hybrids are usually found among weeds and semi-weeds belonging to fugitive, annual and short-lived shuttle, or colonist life-history categories, that is, species with potential life spans of few years. In these groups, hybrids between various species-pairs have been found multiple times in different areas (Nicholson 1905, 1931; Andrews and Hermann 1959; Pettet 1964; Smith 1964; Reese and Lemmon 1965; Williams 1966; Anderson and Lemmon 1972). Reciprocal crosses have been observed in several cases (Limpricht 1887; Nicholson 1905, 1931; Pettet 1964; Smith 1964; Reese and Lemmon 1965; Nyholm 1993). The fugitives, and annual and short-lived shuttles occur in disturbed open habitats that promote the growth of colonies of different species in close proximity, increasing the chance of intermixing and cross fertilization. Among colonists such as Grimmia (Cardot 1890; Culmann 1926; Loeske 1930; Greven 1995), Bryum (Ochi 1954, 1961; Nyholm 1958, 1993), Campylopus (Corley 1969), and Orthotrichum (Ruthe 1873; Philibert 1883; Hedderson 1986), the relatively fast turnover of colonies may increase the possibility for contact between interspecific clones and thus facilitate crosses between related species.

Hybridization is infrequently observed among species with potential life spans of many years growing in stable habitats, such as long-lived shuttles (examples found only in Sphagnum) and perennials (hybrids reported in Dichelyma, Polytrichum, Rhytidiadelphus, and Warnstorfia). Hybrids in these groups have been proposed mainly on the basis of gametophytic variation. This can be partially explained by the fact that these groups are dominated by pleurocarps, in which related species have similar sporophyte morphology, thus making the sporophytic hybrids difficult to detect. On the other hand, they are often unisexual or functionally so, sometimes expressing skewed sex ratios, commonly have reduced sex expression, or are sterile (Stark 2002). They grow in relatively stable habitats, and tend to form large unisexual long-lived and spatially isolated clones with reduced probability of cross-fertilization.

\section{Isolating mechanisms in bryophytes}

Several isolating mechanisms are recognized in flowering plants that act before and (or) after the fertilization (Stebbins 1950; Grant 1981). Some of them possibly occur in bryophytes and are discussed below.

\section{Spatial isolation}

Spatial isolation is an effective barrier in preventing crosses between species. Geographic isolation in vascular plants is often associated with incomplete reproductive isolation (Stebbins 1950). There are indications that this phenomenon occurs in bryophytes as well. Allen (1937) observed that some geographic races of Sphaerocarpos texanus were partly reproductively isolated whereas others were fully interfertile. Similarly, Riella americana has been found to consist of several reproductively isolated geographic races (Proctor 1972). Proskauer (1969) demonstrated considerable reproductive isolation between the species of Phaeoceros, but some geographic races of Phaeoceros laevis were able to intercross under certain circumstances. It is largely un- 


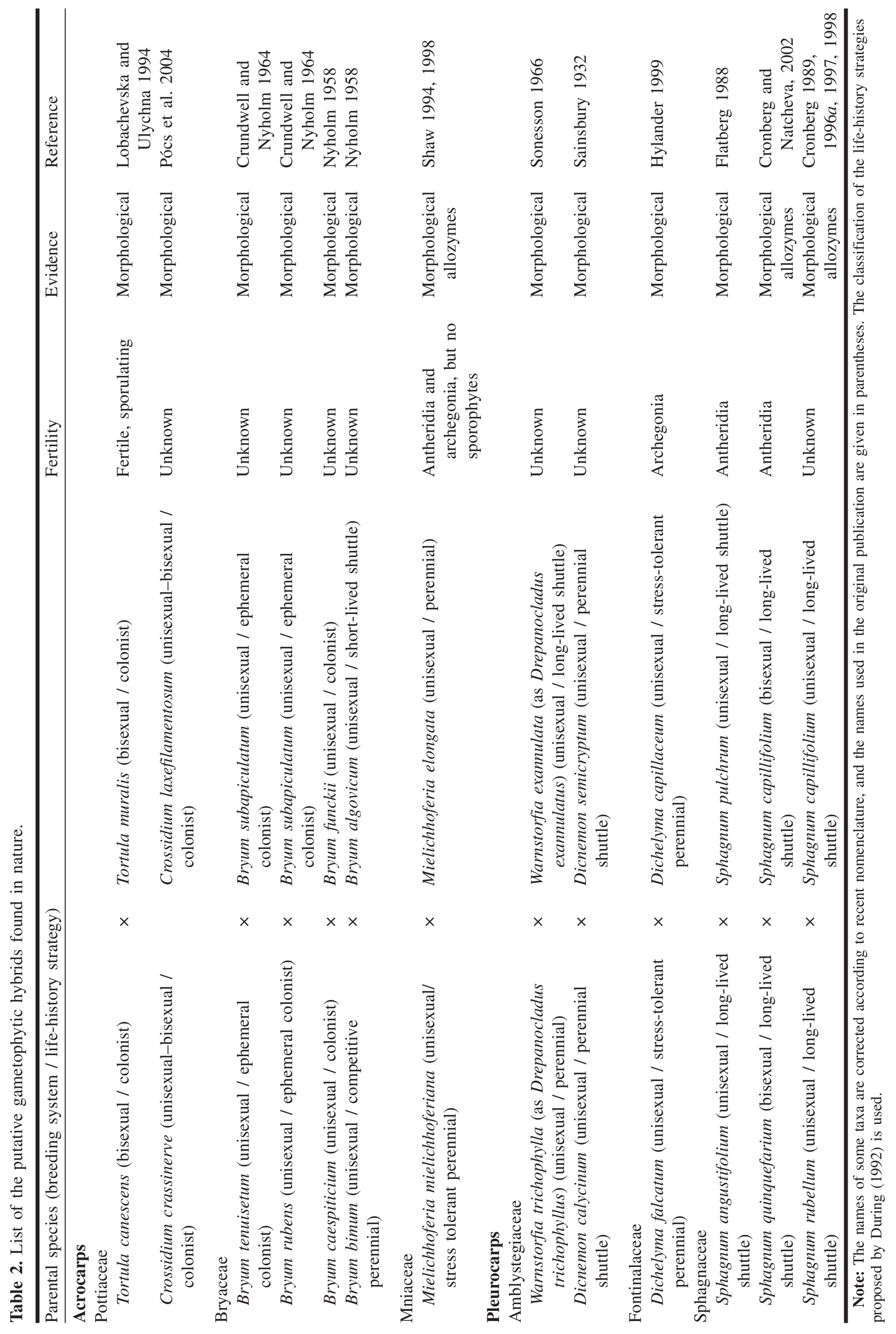


known, however, how widespread reproductive isolation is among allopatric bryophyte species.

Small-scale spatial isolation is a much more effective barrier against interbreeding between bryophytes, which rely on water as an agent for dispersal of motile sperms, than between seed plants, which possess a higher potential for gamete (pollen) dispersal. Gene flow distances via sperms are restricted to few centimetres in most species, reaching up to an extreme of $2 \mathrm{~m}$ in some species with splash-cups (reviewed in Longton and Schuster 1983; Shaw 2000; Van Der Velde et al. 2001). In unisexual species the physical separation restricts the gene flow via gametes not only between clones of different species but also between conspecific clones of the opposite sex (Cronberg 2002). Reduced spatial isolation could account for the over-representation of hybrids among species growing in disturbed open habitats, because such habitats offer more possibilities for meeting and mating.

Ecological isolation in bryophytes is tightly connected with spatial isolation. As Anderson (1980) stressed, short gamete dispersal distances mean that hybridization in nature would occur only between species that have similar ecological requirements and share the same substrate. Exploitation of different niches prevents mating between related species, but hybrids may occur in intermediate or mosaic habitats. For example, Sphagnum capillifolium (Ehrh.) Hedw. and Sphagnum rubellum Wils. typically occupy different niches, the former being more shade tolerant and more minerotrophic, the latter preferring open ombrotrophic habitats. However, it has been shown that they hybridize in intermediate habitats such as lagg-zones of raised bogs, where they occur together, being difficult to separate morphologically as a consequence of hybridization (Cronberg 1989, 1996a, 1997). The two species seem to hybridize more often under oceanic conditions where intermediate habitats are more common (Cronberg 1989). A similar explanation was suggested by Flatberg (1988) when discussing the possibility for an allopolyploid origin of Sphagnum skyense Flatberg that combines morphological features of the ecologically well-differentiated species Sphagnum quinquefarium (Lindb.) Warnst. and Sphagnum subnitens Russow and Warnst.

\section{Reproductive isolation}

Reproductive isolation in bryophytes may be caused by one, or a combination of the following isolating mechanisms: seasonal, gametic, or internal isolation, or selective fertilization.

The importance of the timing of gametangial maturation for reproductive isolation is unknown because of generally poor knowledge about reproductive phenology of related taxa. It has been speculated that the timing of gamete production differs between Sphagnum balticum (Russow) C.E.O. Jensen and Sphagnum tenellum (Brid.) Brid., because the timing of sporophyte maturation and spore liberation differs throughout most of their geographic distribution ranges. Only under certain climatic circumstances, do these periods coincide or at least overlap, which may explain the limited distribution of their endemic allopolyploid product Sphagnum troendelagicum Flatberg (Såstad et al. 2001). Seasonal isolation was suggested to occur also among species of
Weissia (Khanna 1960; Williams 1966), and among the geographic races of Anthoceros (Proskauer 1969).

Gametic isolation could potentially occur as selective attraction of sperms by conspecific archegonia. The nature of the attractants involved in fertilization of bryophytes is largely unknown, but they are probably simple sugars, proteins or inorganic salts (Parihar 1965; Watson 1971), and there is currently no evidence that they are species-specific.

There are no substances known to hamper or prohibit the movement of foreign sperms in the neck of archegonia or to prevent the penetration of sperms of other species into the egg (Anderson and Snider 1982). The observations of Showalter (1926) that egg cells of Fossombronia were penetrated by sperms of Aneura, Sphaerocarpos, Asterella, and Funaria suggest that the initial stage of fertilization is highly unspecialized. Similar lack of selectivity has been found in other archegoniate plants; for example, egg cells of Equisetum were penetrated by sperms of Pteridium, Marsilea, and even Mnium (Duckett et al. 1983).

\section{Internal isolation}

Internal isolation mechanisms can operate at any stage of the life cycle: from fertilization to reproductive maturation of hybrid gametophytes. No data are available relating to abortion of hybrid embryos, which occurs in some cases of hybridization among flowering plants (Stebbins 1950). It is known, however, that the hybrid sporophytes Polytrichum commune Hedw. $\times$ Polytrichum uliginosum (Wallr.) Schriebl. were aborted up to $90 \%$ by the time they matured (Van Der Velde and Bijlsma 2004). In general, sporophyte abortion is common in populations of some species under stressful conditions (Stark 2002).

Internal isolation among bryophytes is usually manifested by sterility of the hybrid sporophytes. Two types of sterility barriers have been demonstrated in bryophytes. Chromosomal (segregational) sterility is expressed during meiosis. It is caused by structural differences in the chromosomes of the parental species that prevent or disturb pairing at meiosis and leads to the formation of spores with imbalanced chromosome sets, carrying deletions or duplications. Anderson and Snider (1982) showed that chromosome pairing failed in hybrid sporophytes of Ditrichum pallidum (Hedw.) Hampe $\times$ Pleuridium acuminatum Lindb. Spores were rarely formed and when so, they were abortive.

Sterility of hybrid sporophytes is attributed to genic imbalance in cases when meiosis is regular, but nonviable spores are produced. In a cytological study of the spontaneous intersectional crosses, Weissia ludoviciana (Sull.) W.D. Reese and B.A.E. Lemmon $\times$ Weissia controversa Hedw., and Weissia muhlenbergiana (Sw.) W.D. Reese and B.A.E. Lemmon $\times$ Weissia controversa, Anderson and Lemmon (1972) observed no irregularities in meiosis. Chromosomes paired normally and chiasma were observed. Both meiotic cell divisions were regular, but abnormalities occurred during spore maturation and differentiation. Some spores were aborted immediately or failed to enlarge, others remained in tetrads or failed to develop chlorophyll. Although the occurrence of cryptic structural rearrangements could not be ruled out, it was assumed that spore sterility in Weissia is genic. Normal meiotic segregation of chromosomes followed by formation of irregular spores was observed in the putative 
allopolyploid Weissia excerta (Broth.) P.C. Chen (Khanna 1960) and was attributed to "disharmonious interactions" of the parental genomes. The artificial intergeneric hybrids in Funariaceae produced by Wettstein $(1924 b, 1928)$ were almost completely sterile, despite regular meiosis.

The effects of combining two divergent genomes are likely to differ at different stages of the life cycle of hybrid progeny. The hybrid sporophyte contains complete genomes from both parents in a heterozygous condition and viability is likely to be maintained if the complementary genomes are not too divergent. In this respect, a parallel could be drawn with the viability of F1 hybrids in seed plants, which often tend to be even more vigorous than the parental species (Grant 1975). Furthermore, the sporophyte is short-lived, physiologically dependent on the gametophyte at least at the beginning of its development, and its single function is spore production and dispersal. In contrast, genic imbalance is likely to have more severe consequences for the haploid hybrid gametophyte, because it combines different parts of parental genomes due to recombination, it is more long-lived and its development involves many critical stages: from spore germination and establishment to maturation of gametes.

\section{Recognizing hybrids}

\section{Morphology of hybrid sporophytes}

Observations of sporophytes that are morphologically intermediate between two species, and thus presumably of hybrid origin, were the first to appear in the scientific literature, and still account for most reports of putative hybrids (Table 1). Typically, parental species have markedly different types of sporophytes; for example, one of the parents has a cleistocarpous immersed spore capsule, and the other has a stegocarpous and exerted spore capsule. In such cases the hybrid sporophyte is readily identified by the noticeable combination of characters of both parents: seta of variable length, irregularly opening spore capsule with a poorly developed operculum, peristome, and annulus. Other examples include crosses between stegocarpous species having peristomate and eperistomate capsules (Hedderson 1986; Culman 1926) or capsules with notably different shape and structure (Ochi 1961).

However, in most pleurocarps, many acrocarps, Sphagnum, and almost all liverworts, the sporophytes of related species are similar or virtually indistinguishable. Therefore, hybridization at the sporophytic stage is likely to remain undetected and the limited number of documented cases may represent a minor subset of the hybrids that actually occur in nature.

Sporophytic hybrids always occur in mixed stands of the parental species. The parents are easily recognized since the hybrid capsule is borne by the female parent and the male must grow within the maximum gamete dispersal distance. In unisexual species, hybridization can sometimes be inferred by the presence of sporophytes in a female colony if the only available male plants belong to a related species. This is the case with the hybrid sporophytes found in Campylopus (Corley 1969), Rhytidiadelphus (Holyoak 2001), and Polytrichum (Van Der Velde and Bijlsma 2004).

Spore quality has sometimes been used to infer hybrid origins (Nyholm 1958, 1993; Crundwell and Nyholm 1964;
Reese and Lemmon 1965; Ochi 1971; Gradstein and Sipman 1978; Rusching and Snider 1985). Unfortunately, in most cases no systematic comparison has been reported with the spore quality of the putative parental species, so it is hard to determine unequivocally if the observed within-capsule variability of spore size and irregularity is a normal phenomenon (like pseudoanisospory or amphispory described by Mogensen 1983), is caused by unfavourable environment, or is owing to hybridization.

\section{Morphology of hybrid gametophytes}

Observations of haploid hybrid gametophytes are much more rare. To a large extend this may be explained by the notorious level of phenotypic plasticity in bryophytes. The problem of determining whether morphological intermediacy is caused by environmental conditions or hybridization has prevented bryologists from identifying hybrid plants that seemingly bridge two species or genera. The first reports of hybrid gametophytes exemplify such problems because they were based on plastic characters such as degree of development of hairs, papillosity, and cell wall thickness (Sanio 1880, 1887; Papp 1925, 1927), and were criticized and rejected by later authors (Klinggraeff 1889; de la Varde 1926; Mönkemeyer 1927; Anderson 1980).

A further complication arises from the fact that hybrids are not necessarily intermediate and not all intermediates are hybrids (Rieseberg 1995). This is especially true for bryophytes because even if the hybrid sporophyte has intermediate morphology, gametophytic progeny results from recombination during meiosis. Recombinants may inherit different parts of the parental genomes, express various combinations of parental traits, or may be more similar to one or the other parent. In many cases even allopolyploid species, which posses full sets of both parental genomes, have been initially considered conspecific with one of the parents-a pattern that is seen both among vascular plants (Stebbins 1950) and bryophytes (Såstad, in press). Further, gametophytic hybrids do not necessarily grow intermixed with their parents. In such cases, it is difficult to readily make morphological comparisons between the parents and putative hybrids in the field, and to evaluate the influence of different environmental conditions.

The high degree of phenotypic plasticity of hepatics is a likely explanation for the absence of observed gametophytic hybrids in nature. Moreover, in thalloid taxa, as well as in many leafy ones, gametophyte structure is rather simple and does not provide enough reliable morphological characters for detecting intermediate character states or combinations of diagnostic characters. In Sphaerocarpos, a genus with species that are known to easily hybridize in culture, potential natural hybrids would not be recognized if the identification is based exclusively on spore morphology. Spore morphology in this genus is maternally inherited and hybrids would routinely be identified as the maternal species (Allen 1930; Doyle 1960). In the extreme case, potential hybrids between sibling species would never be detected from morphological data alone.

\section{Asymmetry of reciprocal crosses}

The limited available data indicate differences between reciprocal crosses. The relevant reports do not provide suffi- 
ciently detailed morphological descriptions to make accurate morphological comparisons between the reciprocals. Nevertheless, there were significant maternal effects on morphology in the experimentally produced sporophytic hybrids, Funaria mediterranea Lindb. $\times$ Funaria hygrometrica Hedw., in both directions of the cross (Wettstein 1926). However, sporophytic hybrids and the allopolyploid derivatives from the cross, Funaria hygrometrica $\times$ Physcomitrium acuminatum Bruch and Schimp., and the reciprocals, were essentially similar (Bauer and Brosig 1959).

Some species intercrossed more easily in one direction than in the other. Wettstein $(1924 a)$ was able to cross female Physcomitrella patens (Hedw.) Bruch and Schimp. with male Physcomitrium pyriforme (Hedw.) Hampe and Funaria hygrometrica, as well as female Physcomitrium eurystomum Sendtn. and male Funaria hygrometrica, but failed to produce any of the reciprocal crosses. Similarly, attempts to produce the hybrids Sphaerocarpos donnellii $\times$ Sphaerocarpos texanus (Allen 1930) and Sphaerocarpos donnellii $\times$ Sphaerocarpos cristatus M. Howe (Doyle 1960) were mostly unsuccessful, but reciprocals were easily obtained. Strongly asymmetric reproductive isolation has been observed between the related species Polytrichum uliginosum and Polytrichum commune (Van Der Velde and Bijlsma 2004). In cases when unisexual clones of the two species grew at close proximity, hybrid sporophytes were identified on female Polytrichum uliginosum but never on Polytrichum commune.

Cross-ability in one or the other direction is important when considering the direction of a possible gene flow between the hybridizing species. Some reciprocal hybrids displayed different degrees of irregularity in spore formation, and thus potentially different levels of fertility. In Weissia the naturally occurring hybrid, Weissia longifolia Mitt. $\times$ Weissia controversa, appeared to be the more successful cross, as the capsules were well developed and spores were produced, while in Weissia controversa $\times$ Weissia longifolia the capsules were often underdeveloped and only abnormal spores were produced (Nicholson 1905; Smith 1964). The hybrids, Physcomitrella patens $\times$ Physcomitrium sphaericum (C.F. Ludw.) Fürnr. (Pettet 1964), produced approximately equal numbers of normal and under-sized spores, whereas the reciprocal produced predominantly small, presumably nonviable spores. On the other hand, no significant difference was observed in spore production by Weissia controversa $\times$ Weissia ludoviciana hybrids in either direction of the cross (Reese and Lemmon 1965).

\section{Genetics of bryophyte hybrids}

\section{The sporophyte phase}

Relatively frequently meiotic irregularities have been observed in both unisexual and bisexual species (Newton, cited in Smith 1978a), and in most instances there was nothing to suggest that hybridization has occurred. Sometimes irregularities have been observed in occasional individuals of species in which meiosis is usually normal. Some of them are certainly owing to outbreeding and structural or genic heterozygosity. However, at least some of these cases might be attributable to hybridization.

An interesting observation was made by Wettstein (1924a, $1928)$ in the experimental crosses, Physcomitrella patens $\times$ Physcomitrium pyriforme and Funaria hygrometrica $\times$
Physcomitrium pyriforme. The hybrid sporophytes were almost completely sterile despite normal meiosis. Occasional tetrads were found in which two spores were viable and two were sterile. In a further cultivation experiment some of the viable spores managed to germinate and gametophytes indistinguishable from the maternal parent were obtained. An analogous observation was made by Ulychna (1977), who found that in the naturally occurring hybrid, Phascum cuspidatum $\times$ Pottia intermedia, two of the spores in each tetrad were smaller and irregular in shape, seemingly nonviable, but the other two were normal. Pettet (1964) found that in the sporophytic hybrid, Physcomitrella patens $\times$ Physcomitrium sphaericum, almost half of the spores were normal and half were smaller and probably nonviable.

Three phenomena could account for such a pattern, all of which may occur in different cases: maternal effects, segregation distortion, and differential survival.

\section{Maternal effects}

Wettstein (1924a) suggested that at meiosis, by chance, the complete maternal genome was segregated and only spores that retained a complete set of chromosomes of the female parent were viable. The two spores in the tetrad, which received the paternal set, were sterile because of incompatibility between the paternal genome and the maternal cytoplasm.

\section{Segregation distortion}

The hybrid progeny may by chance receive more alleles from one parent than would be expected under Mendelian rules of segregation and thus resemble that parent more closely than Mendelian rules would predict (Rieseberg et al. 2000). In such cases, segregation ratios are skewed towards one or the other parental type. This phenomenon was occasionally observed by Allen $(1924 a, 1924 b, 1926)$ in his studies of inheritance of various gametophytic traits, including sex, in Sphaerocarpos.

\section{Differential survival}

Differential survival can be explained by break-up of coadapted genomes or gene combinations, or the cumulative effect of multiple weak negative gene interactions ( $\mathrm{Wu}$ and Palopoli 1994). In the latter case, it would be sufficient to retain a large proportion of one genome intact to minimize the effects of genetic imbalance between divergent genomes. Furthermore, the degree of genome intermixing depends on the recombination rate, which in turn depends on the degree of divergence of the hybridizing species (Rieseberg and Carney 1998). Therefore, the retained proportion of one parent's genome could be of different size depending on the genetic constitution of the parents; that is, their degree of divergence. Intercrossing between more divergent, and potentially less compatible species would more often result in highly sterile sporophytes. Wettstein (1932) emphasized that the more distantly related the parents are, the greater the proportion of nonviable spores. This hypothesis could account for the high level of sterility observed in intergeneric and intersectional hybrids in bryophytes (Nicholson 1905; Andrews and Hermann 1959; Pettet 1964; Smith 1964; Reese and Lemmon 1965; Anderson and Lemmon 1972). It could also explain the observations of interspecific gene flow revealed 
by only restricted exchange of molecular markers between related species in mixed populations (see below).

There is a single study where molecular markers have been used to identify hybrid sporophytes. Van Der Velde and Bijlsma (2004) used additivity at three microsatellite loci to demonstrate the hybrid origin of sporophytes on Polytrichum uliginosum resulting from fertilization by Polytrichum commune.

\section{Occasional misplacement of diagnostic alleles}

The rare occurrence of mixed molecular markers as lowfrequency alleles in otherwise distinct genomes within bryophytes was first discussed by Cronberg (1997). There are several examples of this phenomenon in Sphagnum, which is one of the best-studied genera with respect to isozyme variation. It has occasionally been observed in mixed populations of Sphagnum rubellum - Sphagnum capillifolium (Cronberg 1989, 1996a, 1997, 1998), Sphagnum capillifolium - Sphagnum quinquefarium (Cronberg 1996b; Cronberg and Natcheva 2002), Sphagnum teres (Schimp.) Ångström - Sphagnum rubellum (Cronberg 1996b), Sphagnum affine Renauld and Cardot - Sphagnum austinii Sull. (Thingsgaard 2002), Sphagnum capillifolium - Sphagnum warnstorfii Russow (Natcheva and Cronberg 2003). Plants possessing such mixed markers often do not show morphological intermediacy. As a rule, mixed markers were found in sympatric populations, but not in populations where one of the species is missing, which suggests that the misplaced alleles are not merely rare allelic variants or convergently evolved proteins with the same size and charge, and thus same mobility. There are two exceptions when alien alleles have been found in populations of species, which at present do not occur together at the site, but are otherwise species-specific over a wide geographic area. In one North American population of Sphagnum affine, there was a single individual that possessed an allele otherwise diagnostic for Sphagnum austinii (Thingsgaard 2002). However, Sphagnum austinii did not grow at this site. Similarly, in five populations of Sphagnum capillifolium from Bulgaria, alleles typical of Sphagnum rubellum were detected, but the latter species does not occur in this area at present (Natcheva and Cronberg 2003). Ancient hybridization and extinction were hypothesized to explain these observations.

Interspecific hybridization has sometimes been indicated by incongruence between genome and morphology. In few mixed populations of Sphagnum capillifolium - Sphagnum rubellum (Cronberg 1989) and S. capillifolium - Sphagnum quinquefarium (Cronberg and Natcheva 2002), some individuals identified as one species by their isozyme haplotype, had the morphological expression of the other species. In these populations plants with intermediate morphology and combinations of isozyme markers of the putative parents were also observed.

\section{Recombination of molecular markers and introgression}

Hitherto, only one study has revealed considerable recombination of molecular markers paralleled by relative morphological intermediacy. When growing in allopatric populations, the copper mosses, Mielichhoferia mielichhoferiana (Funk) Loeske and Mielichhoferia elongata (Hoppe and Hornsch.) Nees and Hornsch., are distinguished by alternative alleles at five isozyme loci (Shaw 1994, 1998). When growing in mixed populations, however, recombination was observed between all diagnostic alleles in different individuals. Still, seven out of 11 recombinant haplotypes constructed on the basis of five diagnostic loci had only one allele misplaced (Shaw 1998).

Hybrid indices calculated on the basis of isozyme data were found to be biased towards Mielichhoferia mielichhoferiana in a hybrid zone between Mielichhoferia mielichhoferiana and Mielichhoferia elongata, and interpreted as indicative of introgression (Shaw 1998). This was also reflected by the morphological analysis, which demonstrated that the hybrid types, although on average morphologically intermediate, were closer to Mielichhoferia mielichhoferiana for some traits.

Another putative case of introgression was described by Reese and Lemmon (1965). They compared populations in which hybrid sporophytes between Weissia ludoviciana and Weissia controversa were present and absent. They found occasional plants with the gametophyte and sporophyte morphology of Weissia ludoviciana that produced irregular spores or undivided tetrads. These abnormalities were more frequent at the site where hybrid sporophytes were present, suggesting that these plants had originated through hybridization and subsequent backcrossing with Weissia ludoviciana.

\section{Incongruence between chloroplast and nuclear DNA sequences}

In a recent phylogenetic study of the peat mosses, Shaw and Goffinet $(2000 b)$ revealed that four American species combine chloroplast and nuclear DNA sequences from different sections of the genus. Sphagnum mendocinum Sull. possessed nuclear DNA of sect. Subsecunda, but the chloroplast DNA of sect. Cuspidata. Sphagnum cuculliforme H.A. Crum had nuclear DNA sequences of sect. Subsecunda, but the chloroplast DNA sequences of sect. Sphagnum. Sphagnum falcatulum Besch. and Sphagnum ehyalinum A.J. Shaw and Goffinet combined the nuclear DNA of sect. Cuspidata and chloroplast DNA of sect. Subsecunda. Only Sphagnum mendocinum is morphologically intermediate, whereas the other three species would not have been identified as intersectional hybrids based on morphology alone. Sphagnum falcatulum and Sphagnum ehyalinum morphologically belong to the section Cuspidata, whereas Sphagnum cuculliforme morphologically deviates from any section of the genus. Their ploidy levels are unknown.

\section{Fitness of the hybrid progeny}

The notion that interspecific hybrids of vascular plants are uniformly less fit as compared with their parents is no longer supported. It has been realized that hybrid progeny is highly heterogeneous with respect to fitness both within and beween generations (Rieseberg and Carney 1998). When eval uating the fitness of hybrids it is important to (1) analyse and compare separately different components of fitness and (2) divide and analyse separately different hybrid classes (Arnold and Hodges 1995).

Some preliminary conclusions regarding the fitness of the natural bryophyte hybrids could be inferred from the available reports. 


\section{Fertility and reproductive success}

Many of the reported hybrid sporophytes in bryophytes are nearly or completely sterile (Table 1). These are mainly intergeneric or intersectional hybrids. Others, however, are highly fertile (up to $71 \%$ germination in Astomiopsis amblyocalyx Müll. Hal. $\times$ Astomiopsis exserta E.B. Bartram Snider; Delgadillo 1989).

Putative hybrid gametophytes appear to be fertile in the sense that they produce reproductive organs (archegonia and antheridia). The interspecific hybrids reported in Sphagnum (Flatberg 1988; Cronberg and Natcheva 2002) had seemingly normal antheridia and formed reproductive organs as frequently as the parental species growing in the same environment (Cronberg and Natcheva 2002). It is unknown, however, whether the antheridia produced functional sperms. Putative hybrids between Dichelyma falcatum (Hedw.) Myrin and Dichelyma capillaceum (With.) Myrin were female and developed archegonia, but not sporophytes (Hylander 1999). In Mielichhoferia, the hybrids formed both antheridia and archegonia. The frequency of female stems among hybrids was lower as compared with the parental species, but they were more often male-fertile and the number of perigonia per stem was similar to that of the parents (Shaw 1998). Introgression observed in a hybrid zone of Mielichhoferia mielichhoferiana and Mielichhoferia elongata (Shaw 1998) demonstrated that hybrid gametophytes were fertile and able to backcross with their parents. A putative hybrid population of Tortula canescens Mont $\times$ Tortula muralis Hedw. produced abundant gametangia and sporophytes (Lobachevska and Ulychna 1994). Intermediate plants between Bryum tenuisetum Limpr. and Bryum micro-erythrocarpum Müll. Hall. and Kindb. were also observed to produce sporophytes, though with abnormal or intermediate morphology (Nyholm 1993).

\section{Establishment and survival}

There is little information regarding the fitness and survival of the hybrid sporophytes since most of the reports have been made as single observations. Most of the hybrid sporophytes seem to develop normally to maturity. In some cases, however, hybrid sporophytes may have problems to develop under more unfavourable conditions. The number of vigorous hybrid capsules in two mixed stands of Polytrichum uliginosum and Polytrichum commune decreased during winter, starting from ca. $80 \%$ at the young stage in October and decreasing to $15 \%$ and $70 \%$ in April next year (Van Der Velde and Bijlsma 2004). During the following month the number of hybrid sporophytes decreased to $0 \%$ and $10 \%$, respectively.

Similarly, little is known about the vegetative fitness of hybrid gametophytes in bryophytes. Cronberg (1996a) observed that sporelings of Sphagnum originating from putative hybrids between Sphagnum capillifolium and Sphagnum rubellum were more sensitive to fungal and algal infections when grown on agar medium. Several other attempts to germinate spores from hybrid sporophytes resulted in protonemata that failed to produce gametophores or formed gametophores that died soon (Wettstein 1924a; Reese and Lemmon 1965; Ulychna, 1977). A wide range of viability and growth rates was found among the segregating progeny of the putative hybrid sporophytes of Warnstorfia tri- chophylla (Warnst.) Tuom and T.J. Kop. $\times$ Warnstorfia exannulata (Schimp.) Loeske (Sonesson 1966). On the other hand, the observation that in all mixed populations of Mielichhoferia mielichhoferiana and Mielichhoferia elongata hybrids were found at frequencies ranging from $12 \%$ to 35\% (Shaw 1994, 1998) shows that hybrid spores at least in some cases are capable of establishing viable gametophytes.

\section{Developmental instability}

In a few cases developmental instability because of dissimilar genomes has been suggested as the explanation for observed irregularities in hybrid morphology. The hybrid sporophyte of Phascum cuspidatum Hedw. $\times$ Pottia intermedia (Turner) Fürnr. expressed a novel character curved seta, which was attributed to irregular growth (Ulychna 1977). Cronberg (1996a) found that some clones from a mixed population of Sphagnum capillifolium and Sphagnum rubellum displayed increased variability and asymmetry of stem-leaf shape within individuals. In the same population, isozyme markers indicated hybridization by allele misplacement. Likewise, some of the putative hybrids between Sphagnum capillifolium and Sphagnum quinquefarium showed a tendency to develop hemiisophyllous stem leaves that could also be due to developmental imbalance and inability to completely differentiate the stem leaves (Cronberg and Natcheva 2002).

\section{Significance of natural hybridization among bryophytes}

When considering the evolutionary importance of hybridization we are faced with a paradox. On the one hand, there is substantial evidence that in most cases interspecific matings among vascular plants give rise to progeny with reduced fertility and (or) viability, and the majority of observations suggest that hybrid sporophytes of bryophytes are highly sterile and hybrid gametophytes are rare. On the other hand, there are numerous examples of adaptive introgression and hybrid speciation in angiosperms (Rieseberg 1997), as well as a growing body of evidence for reticulate evolution in bryophytes (Wyatt et al. 1988, 1992; Shaw 2000). This contradiction reflects a fundamental aspect of the evolutionary processes, namely the importance of rare events (Burke and Arnold 2001).

\section{Ephemeral effects}

It has long been assumed that interspecific hybrids among bryophytes are dead-ends with respect to evolution, the argument being that hybrid sporophytes are mostly sterile (Anderson 1980; Smith 1978a). In vascular plants, it has been emphasized that even if few viable pollen grains were produced by the hybrids, these would have an important role as mediators for introgressive gene exchange between species (Stebbins 1950; Stace 1989). This is not the situation among bryophytes. Even if few viable spores are produced by the hybrid sporophytes, the probability for their establishment is low, and even lower for establishment ensuring crossfertilization, given the short gene flow distances via gametes. Thus, there is apparently little chance that the few viable spores, which are eventually produced, are significant for gene transfer between species. Several authors stressed that in most cases when hybrid sporophytes were observed gametophytes of intermediate morphology have not been 
found and that hybrid sporophytes are obviously not selfpropagating (Anderson and Lemmon 1972; Anderson 1980; Hedderson 1986). However, several points should be considered. (1) As already emphasized, the reported hybrid sporophytes may be only the most obvious, and probably the least significant of the cases of hybridization events that actually occur in nature. There are hybridization events indicating that in some cases at least some of the hybrid spores are viable (Delgadillo 1989; Shaw 1994, 1998). (2) Even if the sporophytic hybrid is completely sterile, there is a chance under certain circumstances to regenerate a diploid protonema, and thus give rise to an allopolyploid plant. (3) The case of introgression described by Shaw (1998) shows that hybrid gametophytes may not only be viable but also fertile and able to back-cross with the parental species. Alternatively, polyploidization may occur in an apical somatic cell of the hybrid gametophyte, and a hybrid autopolyploid may be produced, a possibility that has not been explored in bryophytes. (4) If hybridization is taking place in intermediate habitats, which are to some degree suboptimal for parental species, at least some recombinant spores may have a higher fitness than spores derived from normal reproduction of either parental species. (5) Since all genes and gene combinations in the haploid gametophyte are directly exposed to selection, a hybridization event that leads to the formation of a genotype with superior fitness has theoretically a high chance to establish and proliferate vegetatively (and sexually if it happens to be bisexual and self-compatible). Rare formation of especially favourable recombinant genotypes is statistically probable given the large number of spores that is produced by many bryophytes.

\section{Reticulate evolution and hybrid speciation}

There are a number of taxa that combine characters of related species. Some species may even have a hybrid origin. Several examples exist in Sphagnum. The infraspecific taxon, Sphagnum compactum Lam. and D.C. var. expositum (Maas 1966), combines features of Sphagnum compactum and Sphagnum strictum Sull. Sphagnum subfulvum Sjors is similar in some morphological traits to Sphagnum subnitens and in others to Sphagnum fuscum (Schimp.) H. Klinggr. The possibility for introgression with Sphagnum subnitens was first suggested by Sjörs (1980) and the hypothesis of a putative hybrid origin was raised by Björkbäck and Norling (1984). Flatberg (1985) described intraspecific taxa within both Sphagnum subfulvum and Sphagnum subnitens combining characters of both species. Further, Cronberg (1996b) demonstrated that with respect to isozyme allele frequencies Sphagnum subfulvum occupies an intermediate position between Sphagnum fuscum and Sphagnum subnitens, and shares alleles with one or the other species at 11 out of 13 loci.

Complex patterns of intermixed morphological characters are found in other groups; for example Bryum (Nyholm 1958, 1993; Smith 1978b). Ochi (1972) hypothesized that in the Bryaceae hybridization may play an important role in speciation. A complicated pattern of possible hybrid speciation was observed in Brachymenium pulchrum Hook (Ochi 1972). This African species combines the morphological characters of three genera: Brachymenium, Leptostomum, and Anomobryum. It expresses a high degree of variability in gametophyte and sporophyte characters, it is rarely fertile, and if in fruit, the spore capsules are frequently irregularly developed within the same tuft. The spores are also variable in size and sometimes sterile.

Species that link related genera seem to be common in the Pottiaceae. Recently, several new species were described or recognized that combine morphological characters of Phascum and Pottia (Guerra et al. 1990; Herrnstadt and Heyn 1993), or Phascum and Pterygoneurum (Guerra et al. 1994).

\section{Allopolyploidy}

It is beyond the scope of this paper to discuss allopolyploidy in detail, but it deserves attention as a corollary of hybridization with important evolutionary consequences. Several authors (Longton 1976; Smith 1978a) assumed that with few exceptions, polyploid bryophytes are autopolyploids, and thus hybridization followed by chromosome doubling is of little significance. Recent molecular investigations on polyploid bryophytes showed that allopolyploidy is the rule rather than the exception, and is common in both mosses and hepatics (Såstad, in press, and references therein). There has been no substantive electrophoretic study that unequivocally identified any haploid-autopolyploid species pair (Derda and Wyatt 2000). It is commonly thought that allopolyploidization may occur in three ways: by regeneration of diploid gametophytes from the tissues of a hybrid sporophyte (apospory), by production of unreduced spores (diplospory), or by fusion of sporocytes prior to meiosis (syndiplospory). Regardless of its origin, the allopolyploid is reproductively isolated from its parents and represents an independently evolving unit. Furthermore, many of the allopolyploids thus far demonstrated in mosses and liverworts proved to have multiple origins (Wyatt et al. 1988; Wyatt et al. 1992; Boisselier-Dubayle and Bischler 1999; Såstad et al. 2001). Among the mosses, allopolyploids have been found in Mniaceae, Polytrichaceae, and Sphagnaceae. However, haploid hybrid gametophytes have been observed only within the latter family, indicating that in different groups different mechanisms for allopolyploidization probably operate.

Allopolyploids are known not only between congeners but also between more divergent species belonging to different genera. Derda and Wyatt (2000) revealed that Polytrichastrum pallidisetum (Funk) G.L. Sm. and Polytrichastrum ohioense (Renauld and Cardot) G.L. Sm. have originated as intergeneric hybrids between progenitors belonging to the sister genera Polytrichastrum and Polytrichum. An even more complicated origin was found in Polytrichastrum sexangulare (Flörke ex Brid.) G.L. Sm., which was genetically similar to Pogonatum.

The fact that even a few of the interspecific hybrids managed to undergo apospory or diplospory, which are considered rare events, suggests that probably hundreds of interspecific crosses occur (Wyatt et al. 1992). If allopolyploidy is widespread, it is reasonable to believe that hybridization without polyploidization is common as well, at least in some groups of bryophytes.

\section{Conclusions and perspectives for future work}

From the review and analysis presented here, it is clear that interspecific hybridization among bryophytes occurs in 
nature and may have significant evolutionary consequences. Contrary to the long existing tenet that bryophytes never or very rarely hybridize, it is evident that they are not intrinsically unable to hybridize. They are capable of crossing with various degree of success with regard to the sporophytic and gametophytic generation, as long as the reproductive isolation imposed by short gamete dispersal distances and other isolating mechanisms are surmounted. Nevertheless, this review highlights large gaps in our knowledge regarding the frequency of hybridization among bryophytes, the occurrence of hybrids in different taxonomic groups, the inheritance of morphological characters and molecular markers in hybrids, as well as the fitness and actual evolutionary significance of hybrids. To answer these questions several approaches can be employed.

On the first place these are approaches for detecting hybrids. It is important that bryologists more actively and critically search for hybrids. One should consider the possible occurrence of hybrid sporophytes and hybrid gametophytes in mixed stands of related species. More detailed knowledge about the range of morphological variation in putative parental species is essential. Disturbed habitats and habitats with intermediate or mosaic conditions provide possibilities for the breakdown of ecological isolation, and deserves special attention.

Morphological characters alone are unreliable for detecting gametophytic hybrids due to phenotypic plasticity. Therefore, molecular and morphological markers should be combined in a holistic approach whenever possible. Allozyme electrophoresis is a good preliminary tool to infer hybridization at haploid and especially at polyploid level, provided there is enough variation within populations, and the variation over a large part of the distribution range of the species is known. More variable markers (i.e., RFLP, AFLP, RAPD, ISSR, SSR) would have better resolution but in all cases broad geographic sampling is important to distinguish rare from species-specific alleles. With respect to morphological characters, it is advisable to use those that are known to be less plastic. Quantitative characters such as size, degree of papillosity, degree of development of hairs, etc., should be used with caution. A more reliable and informative tool for morphological analysis is the description of stem-leaf shapes by means of image analysis, which has been used to study hybridization among Sphagnum species (Cronberg 1996a, Cronberg and Natcheva 2002). Shape descriptions based on Fourier coefficients have been shown to display a strong heritable component in vascular plants (S. Andersson, H.C. Prentice, R.J. White, and B. Widén, unpublished data).

DNA sequence data can be highly informative in detecting hybrids and their origin. The comparison of chloroplast and nuclear DNA sequences or restriction products of amplified regions (PCR-RFLP) from the chloroplast and nuclear genomes are a valuable tool for determination of parentage for gametophytic hybrids and for finding cases of reticulations between more remote groups. The presence of additivity at variable sites in multi-copy regions of the nuclear genome; that is, the presence of more than one ITS haplotype, was used successfully to detect hybrid origins at diploid and polyploid level in Paeonia (Sang et al. 1995). This approach can potentially be used to account for hybridization in bryophytes as well.
Another set of approaches are those that reveal the features and evolutionary significance of the hybrid progeny. The performance of controlled interspecific crosses will help to more fully understand the mechanisms involved in hybrid formation and properties of bryophyte hybrids. These would shed light on the ability of bryophytes to cross, and would also provide hybrids with known ancestry for further investigation. In particular, molecular methods could be used to test the degree of recombination of parental genomes in the hybrid progeny (Rieseberg et al. 1990; Rieseberg and Noyes 1998). Studying the fertility of natural and artificially produced hybrid sporophytes is essential for revealing the chance of establishment of hybrid gametophytes that could potentially serve as vectors for interspecific gene exchange. It is of interest to investigate the vegetative performance of the hybrid gametophytes under different environmental conditions. Such studies would be even more informative if the ancestry and genetic constitution of the hybrids is known. This would allow conclusions regarding the vegetative fitness of the hybrids and their ability to establish and persist under a given set of conditions.

\section{Acknowledgements}

We are grateful to Jonathan Shaw, Duke University, and two anonymous reviewers for critically reading and commenting on the earlier version of this paper, and for language corrections. Economic support was provided by Ove Almborn's fund.

\section{References}

Allen, C.H. 1924a. The direct results of Mendelian segregation. Proc. Natl. Acad. Sci. U.S.A. 12: 2-7.

Allen, C.H. 1924b. Inheritance by tetrad sibs in Sphaerocarpos. Proc. Am. Philos. Soc. 63: 222-235.

Allen, C.H. 1926. The transmission of the vegetative characters in Sphaerocarpos. Proc. Am. Philos. Soc. 65: 83-89.

Allen, C.H. 1930. Inheritance in a hepatic. Science (Washington, D.C.), 71: 197-204.

Allen, C.H. 1937. Fertility and compatibility in Sphaerocarpos. Cytol. Fujii Jubilee Volume 1937: 494-501.

Anderson, L.E. 1963. Modern species concepts: mosses. Bryologist, 46: 47-66.

Anderson, L.E. 1980. Cytology and reproductive biology of mosses. In The mosses of North America. Edited by R.J. Taylor and L.E. Levotin. California Academy of Sciences, San Francisco, Calif. pp. 37-76.

Anderson, L.E., and Lemmon, B.E. 1972. Cytological studies of natural intergeneric hybrids and their parental species in the moss genera, Astomum and Weissia. Ann. Mo. Bot. Gard. 59: 382-416.

Anderson, L.E., and Snider L.A. 1982. Cytological and genetic barriers in mosses. J. Hattori Bot. Lab. 52: 241-254.

Andrews, A.L. 1918. A new hybrid in Physcomitrium. Torreya, 18: 52-54.

Andrews, A.L. 1942. Taxonomic notes. II. Another natural hybrid in the Funariaceae. Bryologist, 45: 176-178.

Andrews, A.L., and Hermann, F.J. 1959. A natural hybrid in the Ditrichaceae. Bryologist, 62: 119-122.

Arnold, M.L., and Hodges, S.A. 1995. Are natural hybrids fit or unfit relative to their parents? Trends Ecol. Evol. 10: 67-71. 
Bauer, L., and Brosig, M. 1959. Zur Kenntnis reziproker Kreuzungen von Funariaceen. I. Die Bastarde Funaria hygrometrica $\times$ Physcomitrium acuminatum und reziprok. Z. Vererbungsl. 90: 400-408.

Bayerhoffer, J. 1849. Übersicht der Moose, Lebermoose und Flechten des Taunus. Jahrb. Nassau. Ver. Naturkd. 5: 101.

Björkbäck, F., and Norling, L. 1984. Discrimination analysis of stem- and branch leaf variation in Sphagnum subfulvum Sjörs and $S$. subnitens Russow and Warnst. Lindbergia, 10: 169-174.

Boisselier-Dubayle, M.C., and Bischler, H. 1989. Electrophoretic studies in Marchantia polymorpha L. J. Hattori Bot. Lab. 67: 297-312.

Boisselier-Dubayle, M.C., and Bischler, H. 1999. Genetic relationships between haploid and triploid Targionia (Targioniaceae, Hepaticae). Int. J. Plant Sci. 160: 1163-1169.

Boisselier-Dubayle, M.C., Jubier, M.F., Lejeune, B., and Bischler, H.1995. Genetic variability in the three subspecies of Marchantia polymorpha (Hepaticae): Isozymes, RFLP and RAPD markers. Taxon, 44: 363-376.

Britton, E.G. 1895. Contributions to American bryology. IX. Bull. Torrey Bot. Club, 22: 62-68.

Brosig, M. 1953. Zur Kenntnis reziproker Kreuzungen von Funariaceen. Dissertation der Naturwissenschaftlichen Fakultät der Universität München.

Burgeff, H. 1943. Genetische Studien an Marchantia. Gustav Fischer, Jena, Germany.

Burke, J.M., and Arnold, M.L. 2001. Genetics and the fitness of hybrids. Annu. Rev. Genet. 35: 31-52.

Cardot, J. 1890. Un Grimmia hybride. Rev. Bryol. 17: 18-19.

Corley, M.F.V. 1969. Hybrid sporophytes in Campylopus. Trans. Br. Bryol. Soc. 5: 829.

Cronberg, N. 1989. Patterns of variation in morphological characters and isozymes in populations of Sphagnum capillifolium (Ehrh.) Hedw., and S. rubellum Wils. from two bogs in southern Sweden. J. Bryol. 15: 683-696.

Cronberg, N. 1996a. Clonal structure and fertility in a sympatric population of the pear mosses Sphagnum rubellum and Sphagnum capillifolium. Can. J. Bot. 74: 1375-1385.

Cronberg, N. 1996b. Isozyme evidence of relationships within Sphagnum sect. Acutifolia (Sphagnaceae, Bryophyta). Plant Syst. Evol. 203: 41-46.

Cronberg, N. 1997. Genotypic differentiation between the two related peat mosses, Sphagnum rubellum and S. capillifolium in Northern Europe. J. Bryol. 19: 715-729.

Cronberg, N. 1998. Population structure and interspecific differentiation of the peat moss sister species Sphagnum rubellum and S. capillifolium (Sphagnaceae) in northern Europe. Plant Syst. Evol. 209: 139-158.

Cronberg, N. 2002. Colonization dynamics of the clonal moss Hylocomium splendens on islands in a Baltic land uplift area: reproduction, genet distribution and genetic variation. J. Ecol. 90: 925-935.

Cronberg, N., and Natcheva, R. 2002. Hybridization between the peat mosses, Sphagnum capillifolium and $S$. quinquefarium (Sphagnaceae, Bryophyta) as inferred by morphological characters and isozyme markers. Plant Syst. Evol. 234: 53-70.

Crum, H. 1972. The geographic origins of the mosses of North America's eastern deciduous forests. J. Hattori Bot. Lab. 35: 269-298.

Crundwell, A.C., and Nyholm, E. 1964. The European species of the Bryum erythrocarpum complex. Trans. Br. Bryol. Soc. 4: 597-637.

Culmann, P. 1926. Grimmia cardoti $\times$ anodon. Rev. Bryol. 53: 810.
De La Varde, R.P. 1926. Remarques sur l'hybridation des Mousses. Rev. Bryol. 53: 63-66.

Delgadillo, M.C. 1989. Astomiopsis $\times$ altivallis (Musci: Ditrichaceae), a putative interspecific hybrid in Mexico. Bryologist, 92: 225-227.

Derda, G.S., and Wyatt, R. 2000. Isozyme evidence regarding the origins of three allopolyploid species of Polytrichastrum (Polytrichaceae, Bryophyta). Plant Syst. Evol. 220: 37-53.

Douin, M.C. 1927. Remarques critiques sur quelques Céphaloziellacées. Bull. Soc. Bot. France, 75: 712-725.

Doyle, W.T. 1960. Maternal inheritance and interspecific hybrids of the liverwort Sphaerocarpos. Nature (London), 187: 429-430.

Duckett, J.G., Carothers Z.B., and Miller C.C.J. 1983. Gametogenesis. In New mnual of bryology. Edited by R.M. Schuster. The Hattori Botanical Laboratory, Nichinan, Japan. pp. 232-258.

During, H.J. 1992. Ecological classification of bryophytes and lichens. In Bryophytes and lichens in a changing environment. Edited by J.W. Bates and A.M. Farmer. Clarendon Press, Oxford, UK. pp. 1-31.

Ellstrand, N.C., Whitkus, R., and Rieseberg, L.H. 1996. Distribution of spontaneous plant hybrids. Proceedings of the Natl. Acad. Sci. U.S.A. 93: 5059-5093.

Flatberg, K.I. 1985. Studies in Sphagnum subfulvum Sjors, and related morphotypes. Lindbergia, 11: 38-54.

Flatberg, K.I. 1988. Sphagnum angustifolium (Russ.) C. Jens. $\times$ S. pulchrum (Braithw.) Warnst., a gametophyte hybrid. Lindbergia, 14: 4-7.

Geheeb, A. 1876. Notes sur trois éspeces. 1. Bryum inclinatumcaespiticium. Rev. Bryol. 3: 68.

Gradstein, S.R, and Sipman, H.J.M. 1978. Taxonomy and world distribution of Campylopus introflexus and Campylopus pilifer equals Campylopus polytrichoides: a new synthesis. Bryologist, 81: 114-121.

Grant, V. 1975. Genetics of flowering plants. Columbia University Press, New York.

Grant, V. 1981. Plant speciation. Columbia University Press, New York.

Greven, H. 1995. Grimmia Hedw. (Grimmiaceae, Musci) in Europe. Backhuys Publishers, Leiden, The Netherlands.

Guerra, J., Martìnez, J.J., Ros, R.M., and Carrión J.S. 1990. Phascum longipes sp. nov. on gypsum soils from Almería, Spain. J. Bryol. 16: 55-60.

Guerra, J., Ros, R.M., and Cano, M.J. 1994. Pterygoneurum subsessile (Brid.) Jur. var. kieneri Hab. (Musci, Pottiaceae), a putative hybrid. Nova Hedwigia, 58: 507-510.

Hedderson, T.A. 1986. A naturally occurring moss hybrid between Orthotrichum gymnostomum and O. obtusifolium from Newfoundland, Canada. Bryologist, 89: 165-167.

Herrnstadt, I., and Heyn C.C. 1993. New species linking Phascum and Pottia (Pottiaceae). Nova Hedwigia, 57: 135-139.

Holyoak, D.T. 2001. A hybrid sporophyte on Rhytidiadelphus subpinnatus. Bull. Br. Bryol. Soc. 76: 56-58.

Hylander, K. 1999. Intermediates between the pleurocarpous mosses Dichelyma falcatum (Hedw.) Myr., and D. capillaceum (Dicks.) Myr., possibly of hybrid origin. Lindbergia, 24: 59-64.

Khanna, K.R. 1960. Studies in natural hybridization in the genus Weisia. Bryologist, 63: 1-16.

Klinggraeff, H. 1889. Uber die Bastarde bei Farnen und Moosen. Schr. Naturforsch. Gesellsch. Danzig, 7: 172-178.

Kugita, M.A., Kaneko, A., Yamamoto, Y., Takeya, Y., Matsumoto, T., and Yoshinaga, K. 2003. The complete nucleotide sequence of the hornwort (Anthoceros formosae) chloroplast genome: insights into the earliest land plants. Nucleic Acid Res. 31: 716-721. 
Limpricht, K.G. 1887. Die Laubmoose Deuschlands, Oesterreichs und der Schweiz. Leipzig.

Lobachevska, O.V., and Ulychna K.O. 1994. Peculiarities of hybrid population of moss Tortula canescens Mont. $\times$ T. muralis Hedw. from vicinities of Nikolayev (Lviv district). Ukr. Bot. Zh. 51: 84-91.

Loeske, L. 1930. Monographie der Europäischen Grimmiaceen. Nägele, Stuttgart.

Longton R.E. 1976. Reproductive biology and evolutionary potential in bryophytes. J. Hattori Bot. Lab. 41: 205-223.

Longton, R.E, and Schuster R.M. 1983. Reproductive biology. In New manual of bryology. Edited by R.M. Schuster. The Hattori Botanical Laboratory, Nichinan, Japan. pp. 386-462.

Maas, W.S.G. 1966. Untersuchungen über die Taxonomie und Verbreitung von Sphagnum. VI. S. pylaesii Brid. und das boreoatlantische Florelement unter den Torfmoosen in Südamerika. Nova Hedwigia, 12: 270-273.

Mogensen, G.S. 1983. The spore. In New manual of bryology. Edited by R.M. Schuster. The Hattori Botanical Laboratory, Nichinan, Japan. pp. 386-462.

Mönkemeyer, W., von. 1927. Die Laubmoose Europas. Vol. IV. Kummer, Leipzig.

Natcheva, R., and Cronberg, N. 2003 Genetic diversity in the populations of Sphagnum capillifolium (Ehrh.) Hedw. from the mountains of Bulgaria, and their possible refugial role. J. Bryol. 25: 91-99.

Nicholson, W.E. 1905. Notes on two forms of hybrid Weisia. Rev. Bryol. 32: 19-25.

Nicholson, W.E. 1906. Weisia crispa Mitt. $\times$ W. microstoma C. M. Rev. Bryol. 33: 1-2.

Nicholson, W.E. 1910. A new hybrid moss. Rev. Bryol. 37: 23-24.

Nicholson, W.E. 1931. Hybridity among the bryophytes. Rev. Bryol. 4: 138-140.

Nickrent, D.L., Parkinson, C.L., Palmer, J.D., and Duff R.J. 2000. Multigene phylogeny of land plants with special reference to bryophytes and the earliest land plants. Mol. Biol. Evol. 17: 1885-1895.

Nyholm, E. 1958. Illustrated moss flora of Fennnoscandia. II. Musci. Fasc. 3. Swedish natural science research council, Lund.

Nyholm, E. 1993. Illustrated flora of Nordic mosses. Fasc. 3. The Nordic Bryological Society, Copenhagen.

Ochi, H. 1954. Notes on the mosses of Bryaceae in Japan, II. Intergeneric hybrid sporogone between Bryum argenteum var. lanatum (Palis) Bry. eur., and Brachymenium exile. J. Jpn. Bot. 29: 49-51.

Ochi, H. 1961. Mosses of the Bryaceae in Japan and the adjacent regions, Supplement II. Possibly natural intergeneric hybrid (Bryum pallescens $\times$ Pohlia crudoides var. revolvens). Hikobia, 2: 179-184.

Ochi, H. 1971. Preliminary notes on the speciation in the subfamily Bryoideae, Musci. Misc. Bryol. Lichenol. 5: 159-161.

Ochi, H. 1972. Some problems of distributional patterns and speciation in the subfamily Bryoideae in the regions including Eurasia, Africa and Oceania. J. Hattori Bot. Lab. 35: 50-67.

Papp, C. 1925. Plusieurs hybrides et sur une espece rare de mousse de la Moldavie. Ann. Sci. Univ. Jassy, 14: 380 - 383.

Papp, C. 1927. Contribution à l'étude des bryophytes de la Moldavie. Ann. Sci. Univ. Jassy, 15: 148-160.

Parihar, N.C. 1965. An introduction to Embryophyta. I. Bryophyta. Ed. 5. Central book depot, Allahabad.

Petit, C., Bretagnolle, F., and Felber, F. 1999. Evolutionary consequences of diploid-polyploid hybrid zones in wild species. Trends Ecol. Evol. 14: 306-311.
Petrov, S. 1962. Contribution à la flore bryologique de la Bulgarie. Bryophytes de la montagne Belasica. Izv. Bot. Inst. B"lg. Akad. Nauk. 9: 191-199.

Pettet, A. 1964. Hybrid sporophytes in Funariaceae. I. Hybrid sporophytes on Physcomitrella patens (Hedw.) B. \& S., and Physcomitrium sphaericum (Schkuhr) Brid. in Britain. Trans. Br. Bryol. Soc. 4: 642-648.

Philibert, M.H. 1883. Un Orthotrich hybride. Rev. Bryol. 10: 8-13.

Philibert, M.H. 1891. Un nouveau Bryum hybride. Rev. Bryol. 18: 9-12.

Pócs, T., Sabovljeviè, M., Puche, F., Moragues, J.G.S., Gimeno, C., and Kürschner, H. 2004. Crossidium laxefilamentosum Frey \& Kürschner (Bryopsida: Pottiaceae), new to Europe and to North Africa. J. Bryol. 26: 113-124.

Proctor, V.W. 1972. The genus Riella in North and South America: distribution, culture and reproductive isolation. Bryologist, 75: 281-289.

Proskauer, J. 1957. Studies on Anthocerotales V. Phytomorphology, 7: 113-134.

Proskauer, J. 1967. The variable ploidy life history of a monoecious self-fertilizing hornwort (Anthocerotales). Am. J. Bot. 54: 641-642.

Proskauer, J. 1969. Studies on Anthocerotales. VIII. Phytomorphology, 19: 52-66.

Reese, W.D., and Lemmon, B.E. 1965. A natural hybrid between Weissia and Astomum and notes on the nomenclature of the North American species of Astomum. Bryologist, 68: 277-283.

Rieseberg, L.H. 1995. The role of hybridization in evolution: Old wine in new skins. Am. J. Bot., 82: 944-953.

Rieseberg, L.H. 1997. Hybrid origins of plant species. Annu. Rev. Ecol. Syst. 28: 359-389.

Rieseberg, L.H., and Carney, S.E. 1998. Plant hybridization. New Phytol. 140: 599-624.

Rieseberg, L.H., and Noyes, R.D. 1998. Genetic map-based studies of reticulate evolution in plants. Trends Plant Sci. 3: 254-259.

Rieseberg, L.H., Carter, R., and Zona, S. 1990. Molecular tests of the hypothesized hybrid origin of two diploid Helianthus species (Asteraceae). Evolution, 44: 1498-1511.

Rieseberg, L.H., Baird, S.G.E, and Gardner, K.A. 2000. Hybridization, introgression, and linkage evolution. Plant Mol. Biol. 42: 205-224.

Ros R.M., Guerra, J., and Cano, M.J. 1994. Pottia $\times$ andalusica (Musci: Pottiaceae), un híbrido interespecífico en Pottiaceae. Cryptogam. Bryol. Lichénol. 15: 199-204.

Rushing, A.E., and Snider, J.A. 1985. A natural hybrid between Bruchia microspora Nog., and Trematodon longicollis Michx. Monogr. Syst. Bot. Mo. Bot. Gard. 11: 121-132.

Ruthe, R. 1873. Beobachtung zweier durch Bastardbefruchtung entstandener Laubmoosfrüchte zwischen Orthotrichum anomalum Hedw. und Orthotrichum stramineum Hornsch. Hedwigia, 12: 9-14.

Ruthe, R. 1891. Die Laubmoose Deutschlands, Oesterreichs und der Schweiz, 2: 200.

Sainsbury, G.O.K. 1932. Hybridism in mosses. Bryologist, 35: 5861.

Sang, T., Crawford, D.J., and Stussey, T.F. 1995. Documentation of reticulate evolution in peonias (Paeonia) using internal transcribed spacer sequences of nuclear ribosomal DNA: Implications for biogeography and concerted evolution. Proc. Natl. Acad. Sci. U.S.A. 92: 6813-6817.

Sanio, C. 1880. Commentatio de Harpidiis europaeis inductiva. Botanisches Zentralblatt 1, Gratisbeilage: 1-24.

Sanio, C. 1887. Bryologische Fragmente III. 7 Harpidien-Bastarde. Hedwigia, 6: 194-214. 
Schuster, R. 1983. Phytogeography of the Bryophyta. In New manual of bryology. Edited by R.M. Schuster. The Hattori Botanical Laboratory, Nichinan, Japan. pp. 463-625.

Schuster, R. 1991. Diagnosis of new taxa of Hepaticae, I. Jungermanniidae. J. Hattori Bot. Lab. 70: 143-150.

Schuster, R. 1992. The Hepaticae and Anthocerotae of Eastern North America. Vol. 5. Columbia University Press, New York.

Self, S.L., and Crandall-Stotler, B.J. 2001. The systematic status of Pellia $\times$ appalachiana. Botany 2001: Plants for People: 11 .

Shaw, A.J. 1994. Systematics of Mielichhoferia (Bryaceae: Musci). III. Hybridization between $M$. elongata and $M$. mielichhoferiana. Am. J. Bot. 81: 782-790.

Shaw, A.J. 1998. Genetic analysis of a hybrid zone in Mielichhoferia (Musci). In Bryology for the twenty-first century. Edited by J.W. Bates, N.W. Ashton, and J.G. Duckett. Maney Publishing and the British Bryological Society, Leeds, UK. pp. 161174

Shaw, A.J. 2000. Population ecology, population genetics, and microevolution. In Bryophyte biology. Edited by A.J. Shaw and B. Goffinet. Cambridge University Press, New York. pp. 369402.

Shaw, A.J., and Goffinet, B. 2000a. Bryophyte biology. Cambridge University Press, New York.

Shaw, A.J., and Goffinet, B. 2000b. Molecular evidence of reticulate evolution in peat mosses (Sphagnum), including S. ehyalinum sp. nov. Bryologist, 103: 357-374.

Showalter, A.M. 1926. Studies in the cytology of Anacroginae. III. Fertilization in Fossombronia angulosa. Ann. Bot. 41: 37-46.

Sjörs, H. 1980. Does S. subfulvum Sjörs = S. nitidum Warnst.? Bryol. Times, 1: 2.

Smith, A.J.E. 1964. A bryophyte flora of Glamorgan. Trans. Br. Bryol. Soc. 4: 539-596.

Smith, A.J.E. 1978a. Cytogenetics, biosystematics and evolution in the Bryophyta. Adv. Bot. Res. 6: 165-276.

Smith, A.J.E. 1978b. The moss flora of Britain and Ireland. Cambridge University Press, Cambridge, UK.

Smith, A.J.E. 1979. Towards an experimental approach to bryophyte taxonomy. In Bryophyte systematics. Edited by G.C.S. Clarke and J.G. Duckett. Academic Press, New York. pp. 195206.

Sonesson, M. 1966. On Drepanocladus trichophyllus in the Torneträsk area. Bot. Notiser, 119: 379-400.

Stace, C. 1989. Plant taxonomy. 2nd ed. Chapman and Hall Inc., New York.

Stark, L.R. 2002. Phenology and its repercussions on the reproductive ecology of mosses. Bryologist, 105: 204-218.

Stebbins, G.L. 1950. Variation and evolution in plants. Oxford University Press, New York.

Stenøien, H.K., and Flatberg, K.I. 2000. Genetic variability in the rare Norwegian peat moss Sphagnum troendelagicum. Bryologist, 103: 794-801.

Stenøien, H.K., and Såstad, S.M. 1999. Genetic structure in three haploid peat mosses (Sphagnum). Heredity, 82: 391-400.

Såstad, S.M. In press. Patterns and mechanisms of polyploid speciation in bryophytes. In Plant species-level systematics: New perspectives on pattern and process. Edited by F.T. Bakker, L.W. Chatrou, B. Gravendeel, and P. Pelser. Regnum Vegetabile 142. Gantner Verlag, Ruggell, Germany.
Såstad, S.M., Stenøien, H.K., Flatberg, K.I., and Bakken, S. 2001. The narrow endemic Sphagnum troendelagicum is an allopolyploid derivative of the widespread S. balticum and S. tenellum. Syst. Bot. 26: 66-74.

Thingsgaard, K. 2002. Taxon delimitation and genetic similarities of the Sphagnum imbricatum complex, as revealed by enzyme electrophoresis. J. Bryol. 24: 3-15.

Timm, R. 1927. Über Moosbastarde, insbesondere über die Kreuzungen und Mittelformen zwischen Pogonatum aloides (Hedw.) P.B. und P. nanum (Schreb.) P.B. Hedwigia, 69: 1-44.

Ulychna, K.O. 1977. Hybrid sporogones in Phascum cuspidatum, Pottiaceae, Musci. Ukr. Bot. Zh. 34: 155-158.

Van Der Velde, M., and Bijlsma, R. 2004. Hybridisation and asymmetric reproductive isolation between the closely related taxa Polytrichum commune and Polytrichum uliginosum. Mol. Ecol. 13: $1447-1454$

Van Der Velde, M., During, H.J., Van De Zande, L., and Bijlsma, R. 2001. The reproductive biology of Polytrichum formosum: clonal structure and paternity revealed by microsatellites. Mol. Ecol. 10: 2423-2434.

Venturi G. 1881. Une Mousse hybride. Rev. Bryol. 8: 20-22.

Vitt, D.H. 1971 [1972]. Infrageneric evolution, phylogeny, and taxonomy of the genus Orthotrichum (Musci) in North America. Nova Hedwigia, 21: 683-711.

Watson, E.V. 1971. The structure and the life of bryophytes. 3rd ed. Hutchinson University Library, London.

Wettstein, F. von. 1923. Kreuzungsversuche mit multiploiden Mosrassen. II. Biol. Zentbl. 43: 71-83.

Wettstein, F. von. 1924a. Gattungskreuzungen bei Moosen. Z. Indukt. Abstammungs-Vererbungsl. 33: 253-257.

Wettstein, F. von. 1924b. Kreuzungsversuche mit multiploiden Mosrassen. Biol. Zentbl. 44: 145-168.

Wettstein, F. von. 1926. Über plasmatische Vererbung, sowie Plasma- und Genwirkung. Nachrichten der Gesellschaft der Wissenschaften zu Gottingen. Mathematisch- Physikalische Klasse.

Wettstein, F. von. 1928. Morphologie und Physiologie des Formwechsels der Moose. II. Bibliogr. Genet. 10: 1-216.

Wettstein, F., von. 1932. Genetik. In Manual of bryology. Edited by F. Verdoorn. Hague, The Netherlands. pp. 233-272.

Wettstein, F., von.1940. Experimentelle Untersuchungen zum Artbildungsproblem. II. Ber. Dtsch. Bot. Ges. 58: 374-388.

Williams, C. 1966. A natural hybrid in the genus Weissia. Bryologist, 69: 361-365.

Wu, C.I, and Palopoli, M. 1994. Genetics of post mating reproductive isolation in animals. Annu. Rev. Genet. 27: 283-308.

Wyatt, R., Odrzykoski, I.J., Stoneburner, A., Bass, H.W., and Galau, G.A. 1988. Allopolyploidy in bryophytes: Multiple origins of Plagiomnium medium. Proc. Natl. Acad. Sci. U.S.A. 85: 5601-5604.

Wyatt, R., Odrzykoski, I.J., and Stoneburner, A. 1992. Isozyme evidence of reticulate evolution in mosses: Plagiomnium medium is an allopolyploid of $P$. ellipticum $\times P$. insigne. Syst. Bot. 17: $532-550$.

Xu, S. 2000. Phylogenetic analysis under reticulate evolution. Mol. Biol. Evol. 17: 897-907. 